\title{
UNIVERSITYOF
}

FORWARD

THINKING

WESTMINSTER用

WestminsterResearch

http://www.westminster.ac.uk/westminsterresearch

Olympic Experiences: The Significance of Place

Smith, A., Brown, G. and Assaker, G.

This article is (c) Cognizant Communication Corporation and should not be further copied/distributed or hosted elsewhere without the express permission of Cognizant Communication Corporation.

The article was originally published in Event Management, 21 (3), pp. 281-299, 2017 and is available at:

https://dx.doi.org/10.3727/152599517X14942648527518

The WestminsterResearch online digital archive at the University of Westminster aims to make the research output of the University available to a wider audience. Copyright and Moral Rights remain with the authors and/or copyright owners.

Whilst further distribution of specific materials from within this archive is forbidden, you may freely distribute the URL of WestminsterResearch: ((http://westminsterresearch.wmin.ac.uk/)).

In case of abuse or copyright appearing without permission e-mail repository@westminster.ac.uk 


\title{
OLYMPIC EXPERIENCES: THE SIGNIFICANCE OF PLACE
}

\author{
ANDREW SMITH,* GRAHAM BROWN,† AND GUY ASSAKER $\ddagger$ \\ *University of Westminster, London, UK \\ †School of Management, University of South Australia, Adelaide, Australia \\ $\ddagger$ School of Business, Lebanese American University, Byblos, Lebanon
}

\begin{abstract}
Many studies analyze how events affect places, but few examine how places affect events. Existing research suggests that the physical qualities of a venue affect event experiences, but these studies often ignore subtler dimensions of place such as symbolism, affect, and identity. By narrowly focusing on venues, existing research also tends to neglect the fact that event places are perceived at a wider scale also (e.g., the host destination). Whether these wider place factors affect event experiences is the main question addressed by this study. The research involved a quantitative study of spectators who attended the London 2012 Olympic Games. The authors developed and tested a complex model that hypothesized the effects of place on satisfaction using partial least squares structural equation modelling (PLS-SEM). After permissions were gained from the International Olympic Committee and the London Organizing Committee for the Olympic Games, data were collected from over 600 people attending Olympic events. Research was undertaken at three different types of venue: The Aquatics Centre (a purpose-built venue), Greenwich Park (a temporary venue), and Wimbledon (an established venue). The findings showed that both venue attachment and place defined at the wider scale (at the destination level) had significant positive effects on event satisfaction. In addition, we found evidence that the different types of venues—purpose built, temporary, and established-moderated the relationship between venue attachment and event satisfaction. The results support venue attachment as a second-order factor and demonstrate the role of place symbolism within a four-dimensional conceptualization of place attachment. Ultimately, the research suggests that where an event is staged does affect event satisfaction, and this has important implications for the ways the Olympic Games and other large-scale events are staged.
\end{abstract}

Key words: Mega-events; Attachment; Satisfaction; Venues; Symbolism

Introduction

In focusing on how events are staged, and their impacts, the significance of where an event is staged is often neglected in events research. As Van Aalst and Van Melik (2012) identify, although we now understand what events can do for places, there is a "gap in knowledge" as little research explores what places can do for events (p. 196). Our study addresses this gap by examining the relationship

Address correspondence to Andrew Smith, Reader in Tourism and Events, Faculty of Architecture and the Built Environment, University of Westminster, 35 Marylebone Road, London, NW1 5LS, UK. Tel: +442035066658; E-mail: smithan@westminster.ac.uk 
between perceptions of host places and experiences of organized events. Experiencing events affects people's perceptions of places (Kaplanidou \& Vogt, 2007), but do perceptions of host places affect event experiences? This important question is addressed by this study.

The research analyzes event places at two different scales: it examines how perceptions of a host city affect event experiences, but also how attachment to event venues affects those experiences. Place attachment is usually associated with places that attain familiarity via regular interaction, but researchers have shown that people can also become attached to places they visit infrequently (McCabe \& Stokoe, 2004; Yuksel, Yuksel, \& Bilim, 2010). Following this logic, our research explores whether place attachment can help us to understand event experiences. The research contributes to the extensive literature on place attachment but, ultimately, the main aim is to advance understanding of event experiences by analyzing the hitherto underexplored significance of place.

This study focuses specifically on sport venues and event satisfaction. Existing research suggests environmental and venue factors exert an influence on sport event experiences (Hill \& Green, 2000). Our research examines whether place interpreted in a broader sense affects a critical dimension/outcome of event experiences-spectator satisfaction. Following an established tradition in leisure and tourism research, satisfaction is used in this study to represent experiences. Satisfaction involves a judgement about the "level of consumption-related fulfilment” (Zeithaml \& Bitner, 2003, p. 86) and research at sport events suggests that perceptions of the core product (e.g., outcome of a game) and ancillary services (e.g., venue layout) coexist as antecedents of spectator satisfaction (Yoshida \& James, 2010). However, Hightower, Brady, and Baker (2002) suggest that spectators might also be influenced "by peripheral aspects of the sports event such as the environment in which it is held" (p. 704). Our study explores this observation further by examining the influence of event places, and attachment to those places, on satisfaction levels.

To date, no study has examined the relationship between place attachment and event satisfaction, and the London 2012 Olympic Games provided an excellent opportunity to address this gap. A globally oriented, one-off mega-event provides a fascinating context within which to study the role of place generally, and place attachment in particular. If placerelated factors are significant in such an extreme example, we can assume they are significant for events that are geographically rooted. There were other reasons why London 2012 was selected as the case study. The diversity of venues used by organizers allowed our research to compare different types of event places. Olympic events were staged simultaneously in different sorts of venues (new, existing, temporary), in different spaces (in purpose-built parks, in other public spaces, in indoor arenas), and at different locations (centrally, in outlying urban districts). To explore these variations (and their relative effects), our research focused on three contrasting venues: an established venue with an iconic image (Wimbledon), a temporary venue in a prestigious public space (Greenwich Park), and a spectacular arena purposefully built for the occasion (Aquatics Centre).

\section{Event Places}

Research has demonstrated that the sport event environment can influence spectators' motivation to attend and their satisfaction with the experience (Hill \& Green, 2000). Physical environments are often linked to spectator experiences via the notion of the servicescape (Bitner, 1992), which encompasses the ambient conditions, the layout/functionality of the spaces used, and the provision of signs, symbols, and artifacts (Chang, 2000). However, the sport event environment needs to be understood as an emotional one rather than merely as a physical entity. This allows recognition of key phenomena such as atmosphere: "the totality of emotionally appealing environmental stimuli in a defined place" (Wochnowski, 1996, p. 181). According to Uhrich and Benkenstein (2010), excitement induced by the atmosphere in a stadium has positive effects on satisfaction and repatronage intentions. The need to include these affective dimensions in research about sport event experiences is advocated in a study by Theodorakis, Koustelios, Robinson and Barlas (2009), in which the authors acknowledge that their work:

Captured the respondents' cognitions regarding the physical element of the service experience, 
but failed to include any affective reactions to the physical setting of the service. It is therefore possible that the physical element of a sports service might affect repurchase intentions through the concept of affective "place attachment." This could be examined in greater detail in future studies. (p. 467)

Following the same logic, event satisfaction might be influenced by place attachment. This hypothesis is tested by our research at the London 2012 Olympic Games (see H1).

As McClinchey and Carmichael (2010) argue, event places need to be understood at the venue scale, but also at a wider destination scale. This has been recognized in the events literature by examining "the degree to which they [events] are associated with or institutionalized in, a particular community or destination" (Getz, 2008, p. 6). Indeed, Getz (2008) uses this logic to classify different types of event as mega, hallmark, regional, or local. Van Aalst and Van Melik (2012) also identify that events "differ in their degree of place dependency" (p. 195), and argue that in the contemporary era the importance of place for some events "seems to be becoming weaker” (p. 198). Their empirical research tested the idea that the location of an event contributed to its success, and they concluded that place factors were not particularly important to visitors. However, this research was based on a music festival and equivalent work on sport events is very limited. Kaplanidou and Vogt (2007) analyze the effects of host city images on event satisfaction, but it remains unclear whether or not sport event perceptions are affected by perceptions of host destinations. Accordingly, our study tests whether host city perceptions affect levels of satisfaction with an event (H2).

Although some commentators suggest that sport spaces are becoming increasingly sterile (Vertinsky \& Bale, 2004) and venues more placeless (Penny \& Redhead, 2009), events are increasingly linked to places by host cities keen to maximize the outcomes of media coverage. Techniques used include placing destination logos in the field of play and staging events in locations where city icons and skylines are visually integrated. For example, venues used for the 1992 Barcelona Olympic Games were designed so that the city was visible during events. In other cases, iconic venues have been constructed that are designed to represent places (Ren, 2008). Our study includes specific attention to this symbolic dimension by developing and testing a revised place attachment construct that includes place symbolism. This conceptualization and the ideas that underpin it are discussed further below.

\section{Place Attachment}

Analyzing place and human experiences is a key concern in a number of disciplines and knowledge about place attachment is heavily influenced by the research of geographers and environmental psychologists. Some of the early work by geographers adopted a phenomenological approach when discussing distinctions between space and place (Relph, 1976; Tuan, 1974) while environmental psychology has provided theoretical explanations of the interdependencies between environmental characteristics and human perceptions, emotions, and behaviors (Uhrich \& Benkenstein, 2010). Interest in operationalizing environmental stimuli has been accompanied by attempts to measure the dimensionality of place attachment as a construct (Lalli, 1992; McAndrew, 1998).

In a seminal book devoted to place attachment, Low and Altman (1992) suggest the concept involves "an interplay of affect and emotions, knowledge and beliefs and behaviours and actions in reference to place” (p. 5). Based on the biological bonds between a mother and child (Bowlby, 1969), the application of place attachment in environmental contexts initially focused on psychological connections associated with the home (Buttimer, 1980) and residential environments (Ringel \& Finkelstein, 1991) in the belief that length of residence makes it possible to develop relationships with other residents and with the physical attributes of the place (Jorgensen \& Stedman, 2006). However, people may be able to develop connections with places quickly: in a review of over 120 journal articles published in the last 40 years about people-place relations, Lewicka (2011) notes that "one of the most visible new trends in studies of place attachment in the last decade is a growing interest in attachment to places other than permanent residences” (p. 213). This trend is partly a result of the work of leisure researchers who have examined the extent to which recreational settings make it possible to achieve 
desired outcomes. Lakeshore property ownership (Jorgensen \& Stedman, 2006) and recreation activities including fishing (Hammitt, Backlund, \& Bixler, 2006), hiking (Kyle, Graefe, Manning, \& Bacon, 2003; Moore \& Graefe, 1994), and whitewater rafting (Bricker \& Kerstetter, 2000) have been examined in this manner. As societies have become more affluent and mobile, it has been possible for people to seek places where they feel comfortable (Hidalgo \& Hernandez, 2001) and these spatial anchors may afford feelings of attachment. Thus, researchers interested in tourism and events have begun to analyze the significance of place attachment.

\section{Place Attachment and Satisfaction}

There is a limited amount of work on the link between place attachment and satisfaction, and these studies draw "varied" conclusions (Lee, Kyle, \& Scott, 2012). Lee et al. (2012) examine the relationship between place attachment and festival satisfaction and argue that place attachment is the product of satisfaction, although they recommend, "further investigation on this relationship is necessary" (p. 74). The relationship might be bidirectional and our study hypothesizes that place attachment affects satisfaction. This approach is anchored in Prayag and Ryan's (2012) research on tourists visiting Mauritius. Prayag and Ryan (2012) tested whether there was a positive relationship between place attachment and satisfaction, and their findings supported this hypothesis. The authors suggest this is "not surprising" given the contribution of the functional dimension of place to satisfactory experiences. McClinchey and Carmichael (2010) also suggest an explanation for the effects of place attachment on satisfaction: "places serve as storehouses of meanings that capture value in use and frame expectations for experiences" (p. 60). Our study explores if and how attachment to venues affects event satisfaction, and which dimensions of place attachment are most important.

\section{The Dimensions of Place Attachment}

Within the extensive literature on place attachment, researchers have labored over appropriate techniques for conceptualization and measurement. Some advocate the inclusion of social bonding as a dimension of place attachment (Hidalgo \& Hernandez, 2001; Kyle, Mowen, \& Tarrant, 2004; Ramkissoon, Smith, \& Weiler, 2013) as research has shown that meaningful place experiences often occur in the presence of others. Hammitt, Kyle, and Oh (2009) claim that a two-dimensional model of place identity and place dependence has been the most prominently used attachment model by recreation resource researchers. This model has been found to be reliable across various samples and outdoor recreation contexts (Lee et al., 2012). However, support is strongest for using place affect, place dependence, and place identity as the dimensions or subconstructs of place attachment.

Place identity can be traced back to the influential work of Proshansky (1978) and refers to the way place may affirm personal identity. People may identify with places, which are considered unique (Twigger-Ross \& Uzzell, 1996) or to match their own identity (Proshansky, Fabian, \& Kaminoff, 1983), creating a sense that one belongs in a particular place. Place dependence concerns the functional qualities of a place with evaluative judgements made by comparing the merits of alternative locations. Some researchers to measure feelings associated with physical settings (Jorgenson \& Stedman, 2006) have added place affect. This has been studied in terms of emotional reactions to natural environments, which may help create a sense of psychological well-being (Korpela, Hartig, Kaiser, \& Fuhrer, 2001). Presence at a sport venue can be exciting and emotional with spectators experiencing "high levels of pleasure, sensory stimulation and arousal" (Uhrich \& Benkenstein, 2010, p. 217).

The relationship between these dimensions is evident in an events context when the qualities of a venue mean it is able to offer a spectator experience better than any other location, generate a distinctive emotional reaction from spectators, and promote values that are congruent with personal identities. In addition to these established dimensions, place symbolism seems to be an important part of attachment to sport venues. In an early review of social anthropology literature, Low (1992) nominated Wembley stadium as an example of a place to which people are attached for symbolic reasons and, more recently, Stedman (2003) found that the physical environment influenced sense of place 
through symbolic place meanings. People become attached to places not merely due to their utility or resonance, but because they possess strong visual symbols (Smith, 2005a). Sport events can communicate landscapes that come to represent certain sports, events, and places (Smith, 2005b). Olympic hosts have built venues to provide highly symbolic edifices, a trend most visibly demonstrated by the Bird's Nest Stadium in Beijing. Therefore, in our study, the venue attachment construct was conceptualized to include the dimensions of place dependence, place identity, place affect, and place symbolism.

Like previous studies in tourism and leisure (Ramkissoon et al., 2013), our study assumes a second-order reflective scheme. This means that the second-order construct of venue attachment is connected to its lower-order constructs (e.g., place dependence, place identity, place affect, and place symbolism), with arrows pointing from the second-order to the lower-order factors; thus, venue attachment exerts a mutual effect on the first-order constructs of place dependence, place identity, place affect, and place symbolism. This suggests that these lower-order constructs, although distinct, are related and can be accounted for by a common underlying higher-order construct conceptualized, in this case, "venue attachment” (see Becker, Klein, \& Wetzels, 2012; Wetzels, Odekerken-Schroder, \& Van Oppen, 2009).

Using second-order factor models with correlated factors provides a more parsimonious and interpretable model when it is hypothesized that higher-order factors underlie the data (Chen, Sousa, \& West, 2005). Second-order factor models enable matching the level of abstraction when examining the influence between different constructs (Edwards, 2001). As such, it is possible to examine the effect of venue attachment on spectator satisfaction, rather than the influence of the underlying dimensions, which are at a lower level of abstraction. Thus, considering venue attachment as a second-order factor can be supported both theoretically and conceptually. Evidence for statistical feasibility is provided in the data analysis section of this article.

In the context of outdoor recreation research, the dimensions of place dependence and place identity have been found to be reliable across various samples and contexts, yet how each dimension influences other outcomes is not uniform. Each dimension's associations with other outcomes varies across activity contexts, setting types, and individual characteristics (Lee et al., 2012). The dimensional structure of venue attachment might change in different situations, with environmental variations affecting certain types of attachment more than others do. We designed our study in London to make it possible to examine the relative importance of the venue attachment dimensions at three Olympic venues, using a similar abstraction level (i.e., second-order venue attachment on spectator satisfaction) within a single theoretical model (see H3).

\section{Hypotheses}

Our study examines the following hypotheses, which are anchored in the ideas, literature, and evidence discussed previously.

H1: Attachment to a venue has a significant effect on attendees' satisfaction.

H2: Host city perceptions have a significant influence on attendees' satisfaction.

H3: The influence of venue attachment on attendees' satisfaction differs across different types of venues.

\section{The Case Study Venues}

The three London 2012 venues that provide the focus for the present study are ideal cases with which to explore the significance of place to the event experience. These venues were all significant in London's Candidate File submitted to the International Olympic Committee (IOC) during the bidding stage. London's bid promised a "new Aquatics Centre" in the Olympic Park and identified venues outside the Park:

That provide excellent facilities and spectacular backdrops: the World Heritage sites of Greenwich, the Palace of Westminster, and the Tower of London; other iconic locations such as Wembley, Lord’s Cricket Ground, Wimbledon, Horse 
Guards Parade, the Royal Parks, and Eton Dorney. (London 2012, 2004).

As the quote above highlights, each venue was iconic in a different way. The image of Wimbledon is strongly linked with the historical traditions of tennis and the alignment of their brands suited both the event organizers and the venue. Each could see benefits from the potential transfer of associations. However, some who were unhappy about the way Wimbledon's look had to change to accommodate the Games opposed the use of the venue. The Aquatics Centre was the most spectacular piece of new architecture commissioned for the 2012 Games and it was conceived as the gateway to London's Olympic Park. So, in this instance, iconicity related to the new building's location and form. It was designed by one of the world's most famous architects, Zaha Hadid, and just before the Games, an architecture critic commented, "I have no doubt that the longitudinal view of the swim hall will be one of the defining images of the London Games” (Long, 2012, p. 8). From a very early stage in the planning process, a temporary venue at Greenwich Park was the preferred choice for the equestrian events as it offered London's iconic cityscape as a backdrop. It provided views across Maritime Greenwich-an UNESCO World Heritage Site- to Canary Wharf, the Olympic Stadium, and the easterly fringes of the City of London. The Greenwich Park venue was deliberately conceived as one that integrated existing city icons, communicating that the events were hosted in London.

The three venues were also selected because they represent three different types of venue: one that already existed as a sport venue (Wimbledon), one that was new and purpose built for the Olympics (Aquatics Centre), and a temporary arena that only existed for the duration of the Games (Greenwich Park). Each venue was in a different part of London (East, South East, and South West) and because of their contrasting designs, settings, and longevities each has a different relationship to the places in which they are located. This variety helped our study to examine whether the significance of venue attachment on event experiences varied in different types of event venues (H3). Our work also examined whether the specific place attachment dimensions (dependence, affect, identity, symbolism) —and their relationship to satisfaction—varied between venues.

\section{Research Design}

Gaining permission to conduct research in the venues required detailed negotiations with the IOC followed by applications to the London Organizing Committee of the Olympic Games (LOCOG) and venue managers. Eventually, accreditation was gained for eight researchers to administer a survey at the three venues. The researchers, who had been trained to employ techniques to ensure randomized selection, were dispersed across the venues and approached respondents while they took breaks from watching the events. A self-complete instrument was handed to participants and, when completed, collected by the researchers. Researchers then approached the next available person they came across. The process was effective: most people agreed to participate and completed all questions. Participants were required to indicate their level of agreement with multiple statements using a scale of 1 (strongly disagree) to 7 (strongly agree) and provide details about themselves. Due to the limitations of relying on a single measure of satisfaction (Rosen \& Surprenant, 1998), a multiple-item scale was deployed based on the work of Alexandris, Zahariadis, Tsorbatzoudis, and Grouios (2004). The format was consistent with Oliver's (1997) seminal work with items used to measure anchor, success, and global attributions of satisfaction.

Four dimensions were employed to conceptualize the second-order attachment construct in this study: place dependence, place identity, place affect, and place symbolism. These dimensions were derived from previous studies (Bricker \& Kerstetter, 2000; Hammitt, Kyle, \& Oh, 2009; Kyle et al., 2003). The place attachment dimensions and perceptions of the host city were each measured using three statements. Statement items-including those designed to assess place symbolism-were piloted, pretested, and vetted at a preliminary study undertaken at two sports venues in Adelaide, Australia (Brown \& Assaker, 2013). Table 1 exhibits the statements used for the research undertaken at Wimbledon. Equivalent statements were developed 
for research conducted at Greenwich Park and the Aquatics Centre.

\section{Data Analysis Techniques}

Figure 1 illustrates the model tested in this study. It depicts the underlying dimensions for each construct as well as the hypothesized causal relationships between constructs. To test the validity of this model, data analysis was conducted in a series of stages: with exploratory factor analysis (EFA) and principal component analysis (PCA) used to test dimensionality of each construct. These procedures provided the foundation for structural equation modelling (SEM). At this stage, partial least squares structural equation modelling (PLS-SEM) was used rather than the covariance-based structural equation model (CB-SEM) technique. Both can be used to estimate the parameters in hierarchical latent variable models (Becker et al., 2012), but PLS-SEM aims to maximize the explained variance of the dependent latent construct. This contrasts with CB-SEM's objective-to produce the theoretical covariance matrix, without focusing on explained variance (Hair, Ringle, \& Sarstedt, 2011). CB-SEM simultaneously accounts for all the relationships when computing the model parameters whereas PLS-SEM uses an iterative algorithm in which the parameters are calculated using a series of least square regressions among the constructs (after explicitly creating construct scores by weighting the sums of items underlying each construct). As a result, PLS-SEM maximizes the explained variance of all dependent constructs based on how they relate to both their neighboring constructs and underlying variables. The term partial thus emanates from the

Table 1

Items Used for the Study's Constructs and Associated Descriptive Statistics (Wimbledon) ${ }^{\mathrm{a}}$

\begin{tabular}{|c|c|c|c|}
\hline Constructs/Items & Variable Labels & Mean & $S D$ \\
\hline \multicolumn{4}{|l|}{ Place dependence } \\
\hline The Olympic tennis ${ }^{\mathrm{b}}$ competition could not have been held at a better venue & Q14 & 5.9 & 1.5 \\
\hline Wimbledon ${ }^{c}$ is an ideal venue for spectators & Q15 & 5.9 & 1.4 \\
\hline The event was memorable because it was held at Wimbledon & Q16 & 6.0 & 1.3 \\
\hline \multicolumn{4}{|l|}{ Symbolism } \\
\hline When I think about tennis, I picture Wimbledon & Q17 & 4.8 & 1.8 \\
\hline Wimbledon captures the spirit of the Olympics & Q18 & 5.5 & 1.4 \\
\hline Wimbledon will be seen as a symbol of the London 2012 Games & Q19 & 5.0 & 1.6 \\
\hline \multicolumn{4}{|l|}{ Place affect } \\
\hline Wimbledon means a great deal to me & Q20 & 4.2 & 1.7 \\
\hline I am very attached to Wimbledon & Q21 & 3.8 & 1.7 \\
\hline Wimbledon makes me feel alive & Q22 & 3.8 & 1.7 \\
\hline \multicolumn{4}{|l|}{ Place identity } \\
\hline I identify with Wimbledon & Q23 & 3.6 & 1.6 \\
\hline Wimbledon reflects the sort of person I am & Q24 & 3.3 & 1.6 \\
\hline I can really be myself at Wimbledon & Q25 & 3.7 & 1.7 \\
\hline \multicolumn{4}{|l|}{ Host city evaluation } \\
\hline The Games are special because they are in London & Q26 & 6.1 & 1.3 \\
\hline The Games give me the opportunity to experience London & Q27 & 5.2 & 1.7 \\
\hline It is a pleasure to spend time in London & Q28 & 5.9 & 1.3 \\
\hline \multicolumn{4}{|l|}{ Satisfaction } \\
\hline I am glad I decided to attend the London Olympic Games & Q1 & 6.7 & 0.9 \\
\hline It was a good decision to watch the tennis & Q2 & 6.5 & 1.0 \\
\hline I was satisfied with my experience at the event today & Q3 & 6.3 & 1.2 \\
\hline
\end{tabular}

Scale: 1 = Strongly disagree to 7 = Strongly agree.

${ }^{a}$ For the sake of simplicity, and because this table is included for illustrative purposes, items and data refer to the research undertaken at Wimbledon only.

${ }^{\mathrm{b}}$ Tennis was substituted with equestrian and swimming in the questionnaires administered at the other venues.

${ }^{\mathrm{c}}$ Wimbledon was substituted with Greenwich Park and Aquatics Centre in the questionnaires administered at the other venues. 


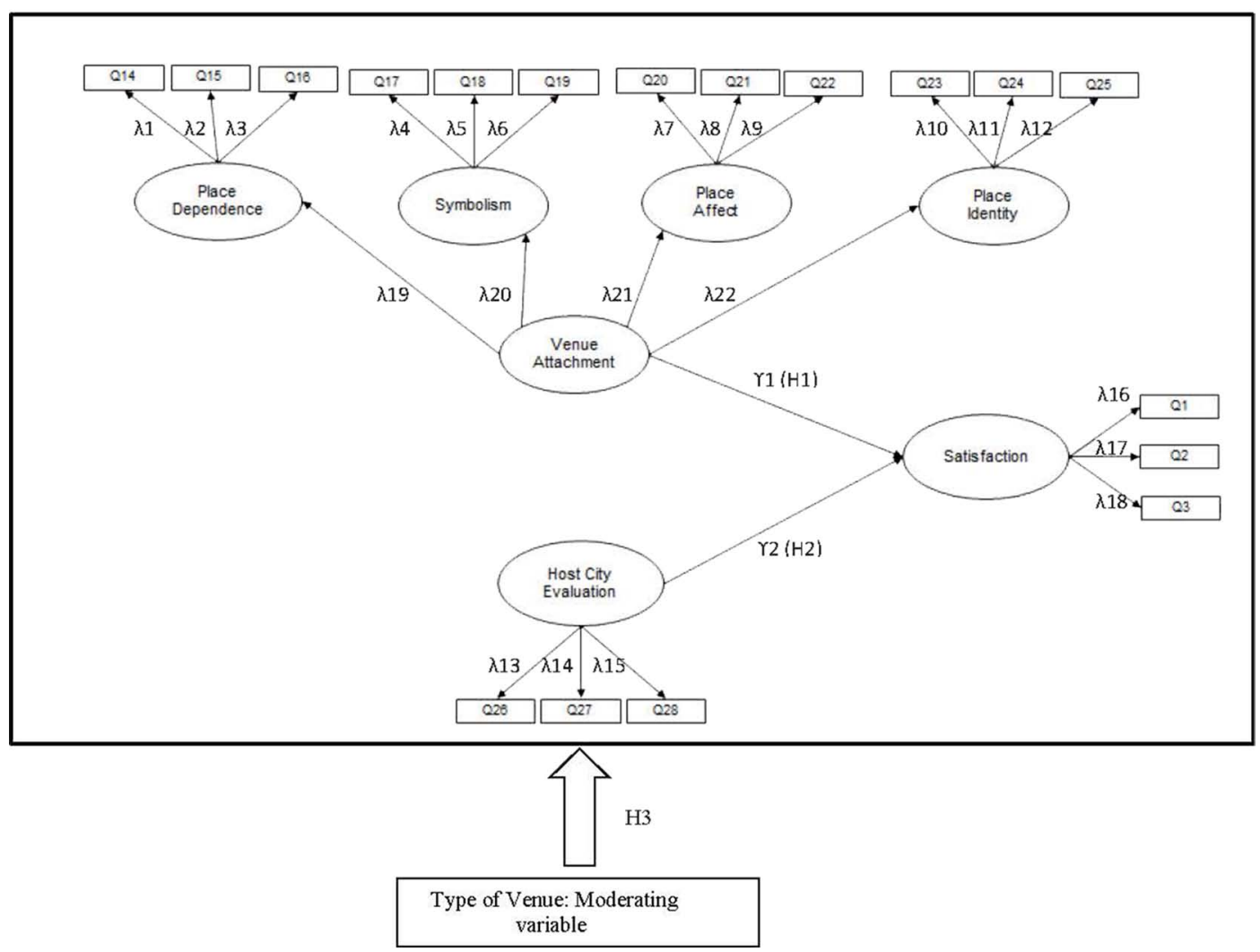

Figure 1. Hypothetical model.

fact that the iterative procedure involves separating the model into parts or "blocks" and estimating parameters for each endogenous construct separately (as the estimates are limited to the immediate blocks to which a particular construct is structurally connected), rather than estimating them for the entire model simultaneously (Hulland, 1999).

The decision to use PLS-SEM in this study was based on the characteristics of the model being tested, and the data under consideration. PLSSEM is a particularly appropriate technique when theoretical explanations are at a preliminary stage of development, for small samples, and where more flexibility is required (Becker et al., 2012; Wetzels et al., 2009). Unlike CB-SEM, PLS-SEM allows researchers to assess the validity of measurements and hypothesized causal paths within one unified model without stringent assumptions about the distribution of the variables (Sato,
Jordan, \& Funk, 2014). We employed PLS-SEM for all these reasons and because our hypothesized model involves higher-order constructs. Hair et al. (2011) advise "if the structural model is complex (many constructs and many indicators), select PLS-SEM” (p. 144).

Our analysis applied PLS-SEM in XL-STAT v. 2011 through two steps: (1) validating the outer model and (2) fitting the inner model. Validating the outer model, which is equivalent to a confirmatory analysis (CFA) in CB-SEM, was accomplished primarily through convergent validity, discriminant validity, and reliability for the first- and secondorder reflective constructs (Wetzels et al., 2009). Only when the outer model is validated does PSLSEM move to validating the internal (causal) relationships among the different constructs. Fitting the inner model was accomplished through a path analysis of the latent variables (i.e., venue attachment, 
host city, and satisfaction), making the second step similar to testing the regression model under CBSEM (Assaker, Hallak, Vinzi, \& O’Connor, 2014).

\section{Sample}

A total of 603 spectators took part in the research: 185 at the Aquatics Centre; 234 at Greenwich Park, and 184 at Wimbledon. Approximately 50\% of participants were aged 30-49 but a wide range of age groups were represented in the sample. Almost a quarter lived in a London Borough, the same proportion (23\%) were from overseas, with the remainder living in the rest of England (44\%) or the rest of the UK (10\%). For $86 \%$ of those questioned, London 2012 was the first Olympic Games they had attended. The profile of spectators was different at each event. The swimming spectators had more experience of attending the Olympics and were more international. The equestrian spectators were slightly older with a high proportion of females and (non-London) UK residents. We have compared our sample to confidential data provided by LOCOG and their survey of ticket holders also indicated a disproportionately high number of females at the equestrian events (64\%) and a higher average age (45). The comparison of our sample profile with the LOCOG data provides reassurance that our sample was broadly representative of the spectators who attended these events.

\section{Results}

\section{Descriptive Statistics}

Our findings suggest that overall satisfaction with the events was very high. Over $60 \%$ of the people we surveyed strongly agreed they were satisfied with their experience. This strong satisfaction was highest at the Aquatics Centre (68\%) and Greenwich Park (65\%) and lowest at Wimbledon (48\%). Overall satisfaction with the venues was also very high. Across the three sites, $47 \%$ strongly agreed that the events could not have been held at better venues. Similar numbers were recorded in responses to the statement that the event was memorable because it was staged at these particular venues: $43 \%$ strongly agreed with this statement. At a wider scale, people also felt that the 2012 Games were special because they were staged in London (54\% strongly agreed).

Although overall satisfaction was lowest at Wimbledon, this venue recorded the most positive figures for the suitability of the venue: $68 \%$ strongly agreed that the events could not have been held at a better venue. Although responses to this question were generally very positive across the three venues, around $10 \%$ of spectators in Greenwich Park felt that equestrian events could have been held somewhere preferable. This was a higher figure compared to the other venues. Spectators were also asked whether the venue helped make the event memorable. Once again, the contribution of the venues was regarded very positively across the three case study sites. The Wimbledon venue seemed to make a particularly positive contribution to this dimension with $63 \%$ of spectators strongly agreeing that "the event was memorable because it was held at Wimbledon." The venues were designed to deliver great experiences for athletes and spectators but also to generate powerful symbolism. The venue regarded as most symbolic of the 2012 Games was the Aquatics Centre; 25\% of those surveyed strongly agreed that this venue would be seen as a symbol of the Games. Spectators felt Wimbledon would probably not be seen as a symbol of the Games.

\section{Preliminary Data Analysis}

EFA using an orthogonal (i.e., Varimax) rotated analysis and associated reliability tests examined the dimensionality and internal consistency for each of the first-order reflective constructs (namely, place dependence, symbolism, place affect, place identity, host city evaluation, and satisfaction), considered separately. This analysis verified whether loadings performed well within each block (i.e., their assigned construct), which supports the unidimensionality of each of the constructs at the present sample level. The EFA and associated reliability tests were also used to examine the dimensionality and internal consistency for the second-order reflective construct (venue attachment). The analysis further provided empirical validation for the reflective scheme for the second-order venue attachment 
factor again at the present sample level. This complements the theoretical support highlighted previously.

To test the dimensionality of each construct, we also conducted a principal component analysis (PCA) on the unstandardized data for the seven reflective blocks of variables (Table 2). The results showed that all first-order constructs (place dependence, symbolism, place affect, place identity, host city evaluation, and satisfaction) and the secondorder reflective construct (venue attachment) were unidimensional, with each represented by one factor with an eigenvalue greater than 1 . In addition, all loadings performed well inside each block (loadings $>0.5$ ), further supporting their unidimensionality. Factor loadings of 0.50 are considered significant given the sample size (Hair, Black, Babin, Anderson, \& Tatham, 2010).
All loadings inside each block fell within a relatively small range. For place dependence, place symbolism, place affect, and place identity, the factors had loadings of $0.82-0.86,0.74-0.81$, $0.88-0.94$, and $0.87-0.92$, respectively. The loadings for host city evaluation ranged from 0.68 to 0.83 and for satisfaction ranged from 0.84 to 0.92 . The second-order construct of venue attachment had loadings between 0.71 and 0.88 . Finally, the Cronbach's alpha and Dillon-Goldstein's rho for the first-order reflective and the second-order venue attachment constructs were robust and above the lower limit of 0.6. This finding is considered satisfactory for confirmatory or exploratory studies (Nunnally \& Bernstein, 1994), indicating high scale reliability and further supporting the unidimensionality and reflective scheme of these factors (see Table 2).

Table 2

Factor Matrix, Cronbach's $\alpha$, Composite Reliability, and Eigenvalues ${ }^{\mathrm{a}}$

\begin{tabular}{|c|c|c|c|c|c|}
\hline Constructs/Variables & Factor 1 & Cronbach’s $\alpha$ & D.G. rho (CR) & Critical Value & Eigenvalues \\
\hline Place dependence & & 0.80 & 0.88 & 1 & \\
\hline Q14 & 0.85 & & & & 2.14 \\
\hline Q15 & 0.86 & & & & 0.48 \\
\hline Q16 & 0.82 & & & & 0.38 \\
\hline Symbolism & & 0.66 & 0.82 & 1 & \\
\hline Q17 & 0.74 & & & & 1.86 \\
\hline Q18 & 0.81 & & & & 0.82 \\
\hline Q19 & 0.79 & & & & 0.32 \\
\hline Place affect & & 0.90 & 0.94 & & \\
\hline Q20 & 0.92 & & & & 2.50 \\
\hline Q21 & 0.94 & & & & 0.33 \\
\hline Q22 & 0.88 & & & & 0.17 \\
\hline Place identity & & 0.88 & 0.92 & & \\
\hline Q23 & 0.89 & & & & 2.41 \\
\hline Q24 & 0.92 & & & & 0.36 \\
\hline Q25 & 0.87 & & & & 0.23 \\
\hline Host city evaluation & & 0.66 & 0.82 & 1 & \\
\hline Q26 & 0.68 & & & & 1.80 \\
\hline Q27 & 0.80 & & & & 0.73 \\
\hline Q28 & 0.83 & & & & 0.47 \\
\hline Satisfaction & & 0.84 & 0.91 & 1 & \\
\hline Q1 & 0.88 & & & & 2.32 \\
\hline Q2 & 0.92 & & & & 0.46 \\
\hline Q3 & 0.84 & & & & 0.23 \\
\hline Venue attachment & & 0.82 & 0.89 & 1 & \\
\hline Place dependence & 0.71 & & & & 2.68 \\
\hline Symbolism & 0.84 & & & & 0.76 \\
\hline Place affect & 0.88 & & & & 0.36 \\
\hline Place identity & 0.84 & & & & 0.20 \\
\hline
\end{tabular}

${ }^{a}$ By reflective variable blocks with component analysis extraction method. 
Based on this analysis, all hypothesized indicators seem to belong together in identifying their underlying constructs. As such, we proceeded with the PLS-SEM analysis to further confirm how well these indicators load on their underlying constructs and to examine the hypothetical causal relationships across the venue attachment, host city, and satisfaction constructs.

\section{PLS-SEM Analysis}

PLS-SEM using XLSTAT software was undertaken on the full dataset of the unstandardized data, using Mode A for the first-order constructs of venue attachment as well as the satisfaction construct. Mode A is the term used in PLS-SEM to refer to reflective measurement models-those involving indicators that are functions of the latent construct where the directional arrows progress from the constructs to the indicators. Mode A was used to relate the second-order latent construct (venue attachment) to the blocks of the first-order latent variables (place dependence, place symbolism, place affect, and place identity) as reflective dimensions. In this case, the loadings between the second-order and first-order factors represent the second-order loadings. Finally, the centroid scheme was also indicated for estimating inner weights.

\section{Outer Model Analysis}

We analyzed the quality of the reflective measurement models using convergent and discriminant validity as well as the reliability of the latent variables. PLS-SEM makes no distributional assumptions; thus, only nonparametric tests can be used to evaluate the explanatory power of the model being examined (Chin, 1998). For the reflective first-order dimensions (place dependence, place symbolism, place affect, and place identity) and the host city and satisfaction constructs, the convergent validity of the constructs was supported because factor loadings were around or above the 0.7 threshold (Table 3). As such, more than $50 \%$ of the variance in the observed variable could be explained by the underlying construct (Hulland, 1999). Furthermore, the bootstrap test showed high significance levels for all loadings (the bootstrap-based empirical 95\% confidence interval does not include zero; see Table 3). This suggests that all indicators reflect their underlying constructs.

The average variance extracted (AVE) achieved values of $0.715,0.599,0.832$, and 0.802 for the firstorder venue attachment dimensions (place dependence, place symbolism, place affect, and place identity, respectively) as well as 0.595 and 0.761 for host city and satisfaction constructs, respectively. Because AVE exceeded the required 0.5 threshold, the constructs captured more than 50\% of the indicators' variance. With respect to discriminant validity, we also examined the cross-loadings and found that all indicators had higher loadings on their respective constructs than on other constructs in our outlined model (Table 4). Only three indicators (Q21, Q22 for place affect, and Q23 for place identity) showed high cross-loadings across the two constructs (place identity and place affect); however, the Q21 and Q22 loadings (0.933 and 0.811) on their hypothesized place affect construct were still greater than their loadings (0.721 and 0.776) on place identity (Table 5). The same was true for the Q23 loading on its hypothesized place identity construct (0.903) compared to the loading on its place affect (0.838). However, both were considered large enough to keep the three items as hypothesized, especially given the close meaning/wording of the items used to measure the two constructs (see Table 1). Furthermore, the average shared variance of a construct and its indicators should exceed the shared variance with every other construct of the model. Thus, the square root of AVE should surpass the correlation coefficient of the construct with every other construct in the model. This is the case in our outlined model (Table 4), further supporting that all constructs and their indicators used in our model were sufficiently different, particularly the place affect and place identity constructs. Finally, the Cronbach's alpha and Dillon-Goldstein's rho for all first-order reflective constructs were robust and well above the lower limit of 0.6 (Nunnally \& Bernstein, 1994), indicating high-scale reliability and further supporting the unidimensionality and reflective scheme of these factors (Table 3).

With respect to the second-order venue attachment construct, Table 3 shows that the Cronbach's alpha and Dillon-Goldstein's rho for that construct 


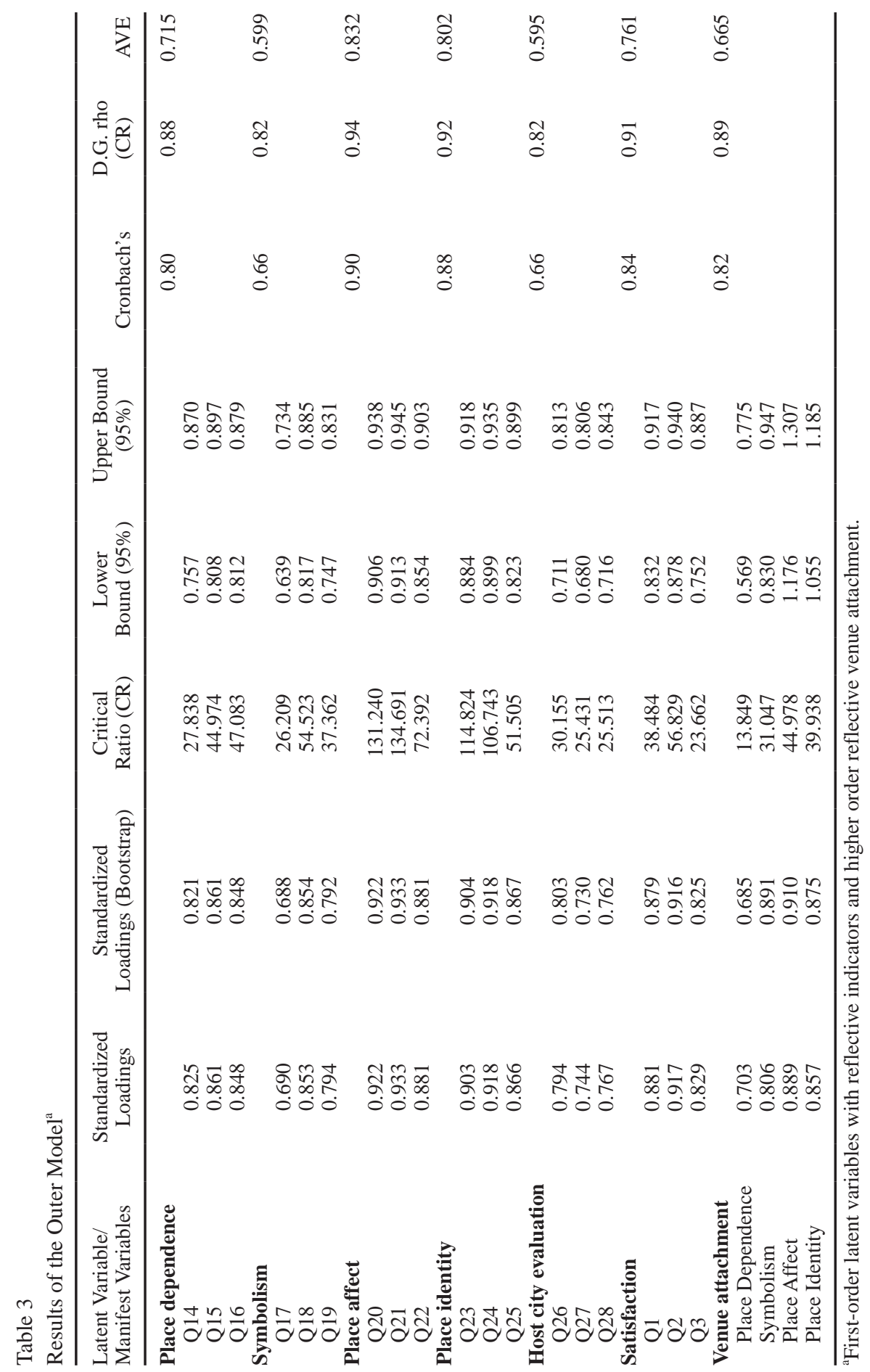


Table 4

Results of Discriminant Validity

\begin{tabular}{|c|c|c|c|c|c|c|}
\hline & $\begin{array}{c}\text { Place } \\
\text { Dependence }\end{array}$ & Symbolism & Place Affect & Place Identity & $\begin{array}{l}\text { Host City } \\
\text { Evaluation }\end{array}$ & Satisfaction \\
\hline Place dependence & 0.845 & & & & & \\
\hline Symbolism & 0.351 & 0.782 & & & & \\
\hline Place affect & 0.189 & 0.342 & 0.912 & & & \\
\hline Place identity & 0.139 & 0.286 & 0.638 & 0.896 & & \\
\hline Host city evaluation & 0.164 & 0.242 & 0.101 & 0.1 & 0.771 & \\
\hline Satisfaction & 0.085 & 0.062 & 0.029 & 0.041 & 0.088 & 0.876 \\
\hline Mean communalities (AVE) & 0.714 & 0.612 & 0.832 & 0.803 & 0.595 & 0.768 \\
\hline
\end{tabular}

${ }^{a}$ First-order latent variables with reflective indicators (squared correlations for any pair of latent variables $<$ AVE).

were greater than 0.6. Moreover, the AVE of the measures were greater than 0.5. The Cronbach's alpha, Dillon-Goldstein's rho, and AVE show evidence of reliability and convergent validity, respectively; in other words, taken together, the first-order constructs (place dependence, place symbolism, place affect, and place identity) represent the second-order factor well and are thus good measures. Furthermore, the loadings of the first-order latent constructs on the second-order factor exceeded 0.7 in standard value, with results indicating that all loadings are significant at the bootstrap-based empirical 95\% confidence interval (Table 3). This further supports the fact that the first-order factors, taken simultaneously, load well on or represent the second-order venue attachment factor well.

\section{Inner Model Analysis and Path Estimates}

The $R^{2}$ results of the tested model demonstrated that an acceptable part of the variance of the

Table 5

Results of Cross-Loadings ${ }^{\mathrm{a}}$

\begin{tabular}{|c|c|c|c|c|c|c|}
\hline & Place Dependence & Symbolism & Place Affect & Place Identity & Host City Evaluation & Satisfaction \\
\hline Q14 & 0.825 & 0.427 & 0.287 & 0.247 & 0.327 & 0.165 \\
\hline Q15 & 0.861 & 0.504 & 0.358 & 0.325 & 0.348 & 0.271 \\
\hline Q16 & 0.848 & 0.560 & 0.443 & 0.362 & 0.359 & 0.289 \\
\hline Q17 & 0.558 & 0.690 & 0.527 & 0.428 & 0.277 & 0.008 \\
\hline Q18 & 0.454 & 0.853 & 0.428 & 0.410 & 0.418 & 0.290 \\
\hline Q19 & 0.365 & 0.794 & 0.406 & 0.411 & 0.465 & 0.293 \\
\hline Q20 & 0.442 & 0.586 & 0.922 & 0.691 & 0.307 & 0.119 \\
\hline Q21 & 0.391 & 0.500 & 0.933 & 0.721 & 0.284 & 0.135 \\
\hline Q22 & 0.357 & 0.514 & 0.881 & 0.776 & 0.280 & 0.210 \\
\hline Q23 & 0.372 & 0.524 & 0.838 & 0.903 & 0.257 & 0.170 \\
\hline Q24 & 0.297 & 0.447 & 0.700 & 0.918 & 0.275 & 0.169 \\
\hline Q25 & 0.330 & 0.464 & 0.590 & 0.866 & 0.323 & 0.204 \\
\hline Q26 & 0.387 & 0.404 & 0.270 & 0.260 & 0.794 & 0.282 \\
\hline Q27 & 0.243 & 0.377 & 0.226 & 0.241 & 0.744 & 0.201 \\
\hline Q28 & 0.287 & 0.348 & 0.230 & 0.223 & 0.767 & 0.188 \\
\hline Q1 & 0.242 & 0.221 & 0.128 & 0.167 & 0.315 & 0.881 \\
\hline Q2 & 0.244 & 0.220 & 0.174 & 0.211 & 0.227 & 0.917 \\
\hline Q3 & 0.283 & 0.210 & 0.144 & 0.151 & 0.239 & 0.829 \\
\hline
\end{tabular}

${ }^{\mathrm{a}}$ First-order latent variables with reflective indicators. 
satisfaction construct can be explained by the host city as well as the second-order venue attachment constructs $\left(R^{2}=0.167\right)$. The cross-sectional regressions for the first-order venue attachment dimensions (place dependence, place symbolism, place affect, and place identity at $0.455,0.650,0.812$, and 0.752 , respectively) provided the explained variances for at least $15 \%$ of the satisfaction construct (Hair et al., 2010). These results concur with the threshold proposed by Chin (1998), whereby the $R^{2}$ values of $0.670,0.333$, and 0.150 in PLSPM are considered substantial, moderate, and satisfactory, respectively. As such, the nomological validity of the model is considered satisfactory.

A final assessment of the structural model involved estimating the path coefficients among venue attachment, host city, and satisfaction. To do so, we ran a bootstrapping with 5,000 iterations of resampling (Davison \& Hinkley, 1997). Figure 2 depicts the inner model results along with the bootstrapping results. The path coefficients (Fig. 2) showed that venue attachment had a significant positive impact on satisfaction $\left(\gamma_{1}=0.172\right.$, $t$-value $=3.982$ ), thereby supporting hypothesis $\mathrm{H} 1$, with place affect and venue identity being the most important dimensions of venue attachment ( $\lambda_{21}=0.889$ and $\lambda_{22}=0.857$, respectively). There was also support for hypothesis $\mathrm{H} 2$ as it was found that the evaluation of the host city had a significant positive impact on event satisfaction $\left(\gamma_{2}=0.221\right.$, $t$-value $=5.101)$.

\section{Multigroup Analysis}

Multigroup analysis was used to test the hypothesis that the influence of venue attachment on attendees' satisfaction differs across different types of venues (H3). In this analysis, we first placed responses into three groups according to the different venues where data were collected (Group 1 = Aquatics Centre; Group 2 = Greenwich; Group $3=$ Wimbledon). We then performed a group comparison to test for the moderating effects of the different types of venues on the relationship between place attachment and spectator satisfaction.

Multigroup comparisons offer one way to test for moderating effects in CB-SEM environments, but have only recently been incorporated into PLS-SEM. CB-SEM uses a global fit criterion (Chi-square difference test, etc.) that allows for a

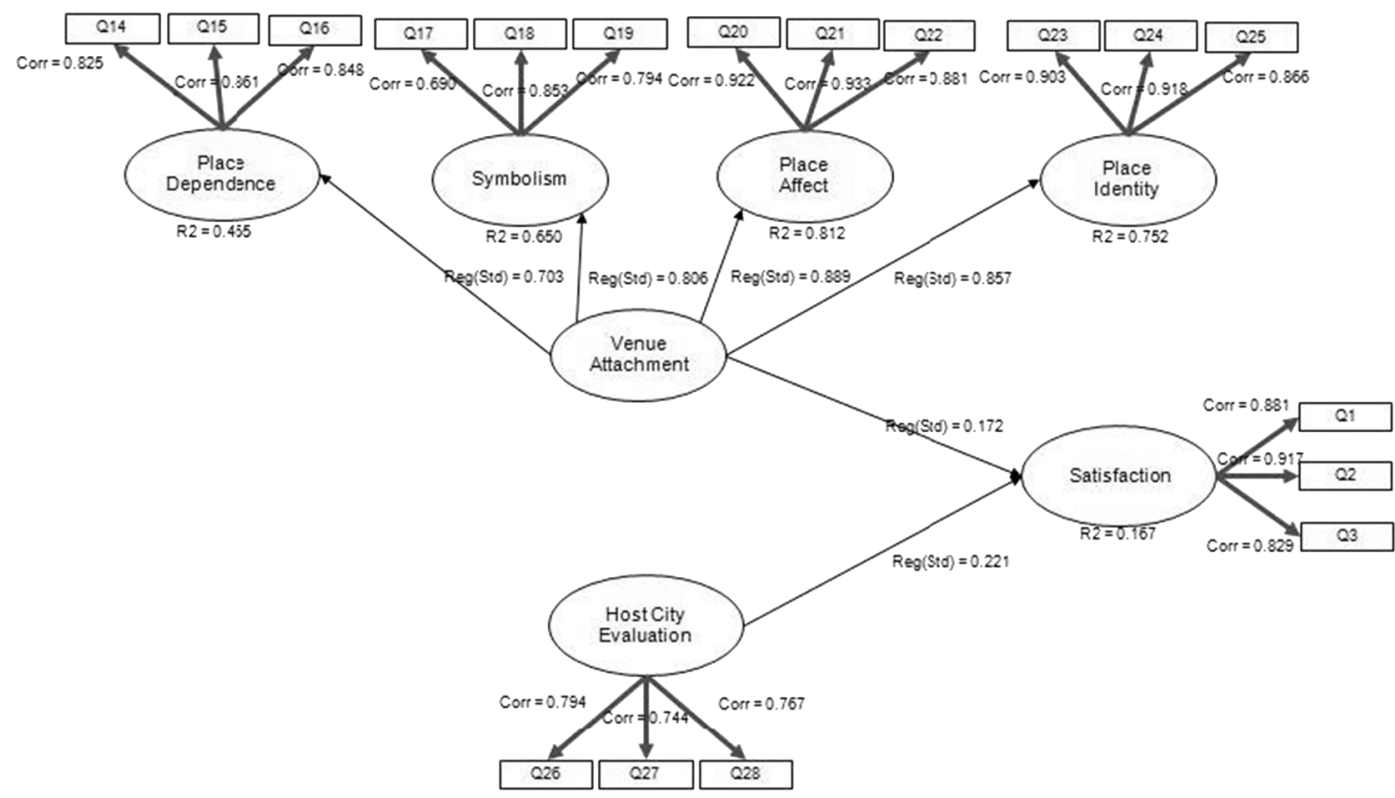

Figure 2. Hypothetical model and associated results. Correlations for the variables for each construct are indicated next to the arrows. 
statistical assessment of the group differences in terms of the structural invariance (full set of structural relationships among constructs, taken simultaneously) across the groups. Although PLS-SEM does not allow for comparing groups using a global criterion, the loadings between each construct and its indicators as well as the path coefficients among the constructs can be compared, one path at a time, across the three venues using multigroup $t$ tests and permutation tests in XL-STAT v. 2011 (Vinzi \& Russolillo, 2010). This approach allows for interpreting the differences in the importance of the dimensions used to measure venue attachment as well as in the relationships among the constructs (i.e., venue attachment and satisfaction from one side and host city evaluation and satisfaction from the other side) across the three venues.

The results revealed equivalent loadings across the three venues, suggesting that the constructs can be measured identically across the different venues (see Table 6). Findings from both tests revealed differences in three of the path coefficients: venue attachment $\rightarrow$ satisfaction, host city $\rightarrow$ satisfaction, and place dependence $\rightarrow$ venue attachment. These results support our hypothesis that model parameters differ across the three venues (H3). The effect of venue attachment on satisfaction was less significant for the spectators attending Wimbledon as opposed to spectators at the Aquatics Centre or Greenwich Park. The results also revealed that the effect of host city evaluation on satisfaction was greater with regard to spectators at Greenwich Park than at Wimbledon or the Aquatics Centre. Although the place affect, place identity, and place symbolism dimensions showed similar weights on venue attachment across the three venues (see Table 6), place dependence had a less significant influence on venue attachment at Greenwich Park.

\section{Discussion and Conclusions}

Several authors have called for more research on the relationship between events and place (Lee et al., 2012; McClinchey \& Carmichael, 2010; Van Aalst \& Van Melik, 2012), with sports event research on this theme notably underdeveloped. Our study responded to this gap in the literature by assessing the influence of place on the experiences of sport event spectators. This type of research is important

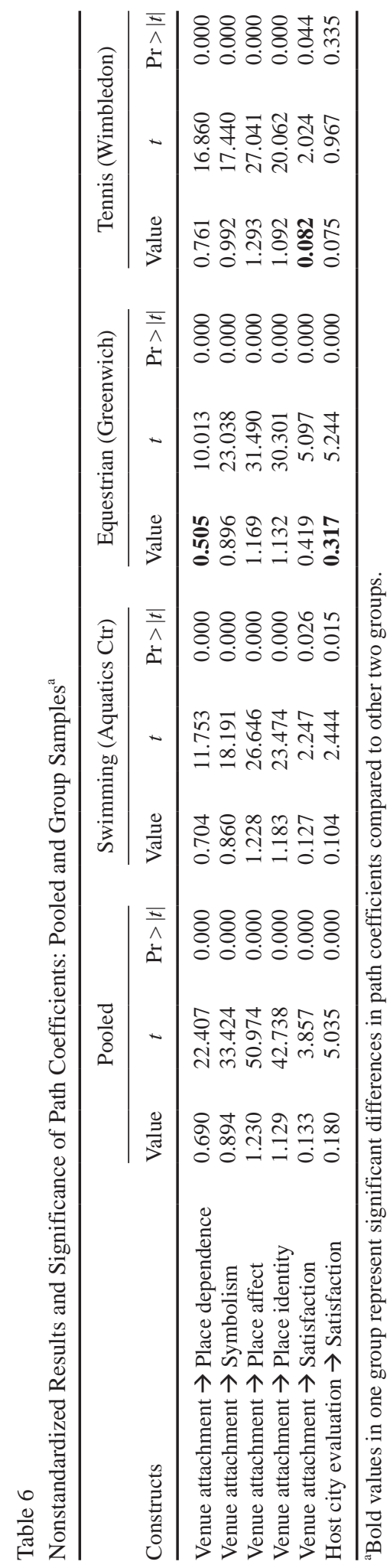


because it helps us to understand why people like events and what affects consumer experiences. Our research drew on established work on place attachment to explore the relationship between venue attachment and event satisfaction. It may seem incongruous to apply place attachment in the context of transient events, but our work reflects recent studies that analyze place attachment in settings, which are inhabited only temporarily (Lewicka, 2011). The influence of place was examined at two different levels: the host city scale and the venue scale, and this multiscale approach could be used in future events studies, but also in more general research on leisure/place relationships.

Spectators completed questionnaires while attending the London 2012 Olympic Games and so the study is a rare example of academic research that was conducted within venues during Olympic competitions. By using an innovative technique (PLS-SEM) to test a complex model, this study also introduces an alternative method of data analysis that other event researchers could emulate.

However, the limitations of a purely quantitative approach to the analysis of phenomena as complex and personal as place experiences are acknowledged. Our work could be complemented by studies that explore the same issues using more flexible, participant-centered methods. The structured research instrument and the focus on place in our study meant that some potentially significant influences on satisfaction levels were not assessed such as the specific influence of variable event content (e.g., the performances of athletes). However, the methods we employed made it possible to assess whether attitudes towards place affect event satisfaction. This contrasts with existing research that analyzes the effects of event satisfaction on attitudes towards place; and further investigations are now needed on this relationship to confirm whether it is a bidirectional one.

There are clear findings that emanate from our study. Spectators were very satisfied with their experiences and this satisfaction was influenced by attachment to event venues (supporting H1). Place affect and place identity were found to be the most important dimensions of place attachment in the context of Olympic event venues. This is not surprising due to the atmosphere at the 2012 Games and because of the meanings attributed to the venues-which spectators clearly identified with. The noted importance of place affect is consistent with research that links affective place images to the Olympic Games (Kaplanidou, 2006) and findings that highlight the emotional dimension of sport venues (Uhrich \& Benkenstein, 2010). The significance of place identity noted here corresponds with research that finds "spectating at the Olympic Games creates and reinforces a sense of belonging” (Shipway \& Kirkup, 2011, p. 136) and it reaffirms that people become attached to places that are personally meaningful (Twigger-Ross \& Uzzell, 1996). Ultimately, our findings demonstrate that event professionals need to look beyond the perceived functionality of event places towards the emotional, personal, and symbolic dimensions. They can increase satisfaction levels by providing venues that evoke emotions and that reflect the identities of spectators.

Place defined at the wider scale-at the host city level—also had a positive effect on event satisfaction (supporting H2). The London-ness of the Games was significant, justifying decisions made by event organizers about venue locations, which promoted connections between the event and the host city. This contradicts recent festival research, which found place to be relatively unimportant to visitors and where the role of wider host city was deemed insignificant (Van Aalst \& Van Melik, 2012). Previous research suggests that emphasizing an event's connections to the host city is only beneficial for the host city, but our research suggests it also benefits events-by enhancing spectator satisfaction. This helps to justify the trend for staging events that are integrated visually and symbolically with the host city.

The organizers of the 2012 Games adopted an innovative approach towards the use of temporary and existing venues, and our findings supported the hypothesis (H3) that different types of venues moderated the relationship between venue attachment and satisfaction. The design of our study made it possible to compare the findings at the three venues and to identify the relative importance of the different dimensions of the venue attachment construct. The results demonstrate that different types of venue (existing sports stadia, iconic new structures, and spectacular public spaces) achieve different outcomes. In line with the objectives of 
the event organizers, the venue regarded as most symbolic of the 2012 Games was the Aquatics Centre-a new, purpose-built venue. Despite calls for the increased use of existing or temporary venues for the Olympic Games (IOC, 2015), this finding suggests there is a symbolic justification for constructing new venues. Another significant finding was the greater influence that perceptions of the host city had on the event attendees' satisfaction at Greenwich Park. This suggests that the visual integration of the venue with London's landscape was influential in shaping experiences. However, our research also found that place dependence was less significant at the Greenwich Park venue. Synthesizing these findings highlights an important trade off. Using temporary venues to accentuate city links may increase satisfaction levels, but effects may be tempered because of the lower functional rating of these venues.

Our study contributes to a better understanding of events and event experiences, but it also furthers understanding of place attachment. Many of the studies reported in the leisure literature have focused attention on the role of place attachment in natural environments (Kyle et al., 2003; Moore \& Graefe, 1994) but this study demonstrates the applicability of the concept in urban event settings. Our findings reaffirm that place attachment can occur in unfamiliar environments, but they go beyond this by proving that attachment can be influential in newly constructed places and in temporary places. Even in these extreme instances, psychological bonds with venues are still important. The venues where place attachment had the most influence on satisfaction were the Aquatics Centre and Greenwich Park, and this effect was driven more by symbolic qualities of place than functional ones. This challenges existing explanations for the positive relationship between place attachment and satisfaction (Prayag \& Ryan, 2012).

The approach adopted here is innovative, because the place attachment construct has not merely been applied; it has been adapted and modified by developing and testing the concept of venue attachment. This can now be used as an independent variable in future studies into event experiences. The dimensions of place dependence, place affect, and place identity, which have been employed in many previous studies, all influenced attachment to venues. Our study has made an additional contribution by identifying the symbolic dimension, which also influenced venue attachment at the Olympic Games in London. This symbolic dimension may be particular to iconic sports stadia so it is hoped that future studies will test our findings at different types of events. Such studies should seek additional evidence about the role played by venue symbolism in venue attachment and should explore the relationship between venue attachment and the event experience.

\section{References}

Alexandris, K., Zahariadis, P., Tsorbatzoudis, C., \& Grouios, G. (2004). An empirical investigation of the relationships among service quality, customer satisfaction and psychological commitment in a health club context. European Sport Management Quarterly, 4, 36-52.

Assaker, G., Hallak, R., Vinzi, V. E., \& O’Connor, P. (2014). An empirical operation-alization of countries' destination competitiveness using partial least squares modeling. Journal of Travel Research, 53(1), 26-43.

Becker, J., Klein, K., \& Wetzels, M. (2012). Hierarchical latent variable models in PLS-SEM: Guidelines for using reflective-formative type models. Long Range Planning, 45, 359-394.

Bitner, M. J. (1992). Servicescapes: The impact of physical surroundings on customers and employees. Journal of Marketing, 56(2), 57-71.

Bricker, K. S., \& Kerstetter, D. L. (2000). Level of specialisation and place attachment: An exploratory study of whitewater recreationists. Leisure Sciences, 22, 233-257.

Bowlby, J. (1969). Attachment and loss, Volume 1: Attachment. New York: Basic Books.

Brown, G., \& Assaker, G. (2013). Exploring place attachment: An empirical analysis of sports events spectators [online]. In J. Fountain \& K. Moore (Eds.), CAUTHE 2013: Tourism and global change: On the edge of something big (pp. 41-52). Christchurch, NZ: Lincoln University.

Buttimer, A. (1980). Home, reach and the sense of place. In A. Buttimer \& D. Seamon (Eds.), The human experience of space and place (pp. 166-187). New York: St. Martin's Press.

Chang, K. (2000). The impact of perceived physical environments on customers' satisfaction and return intentions. Journal of Professional Services Marketing, 21(2), 75-85.

Chen, F. F., Sousa, K. H., \& West. S. G. (2005). Testing measurement invariance of second order factor models. Structural Equation Modeling, 12, 471-492.

Chin, W. W. (1998). The partial least squares approach to structural equation modeling. In G. A. Marcoulides (Ed.), Modern methods for business research (pp. 295-336). Mahwah, NJ: Lawrence Erlbaum Associates. 
Davison, A. C., \& Hinkley, D. V. (1997). Bootstrap methods and their applications. Cambridge, UK: Cambridge University Press.

Edwards, J. R. (2001). Multidimensional constructs in organizational behavior research: An integrative analytical framework. Organizational Research Methods, 4(2), 144-192.

Getz, D. (2008). Event tourism: Definition, evolution, and research. Tourism Management, 29(3), 403-428.

Hair, J. F., Black, B., Babin, B., Anderson, R. E., \& Tatham, R. L. (2010). Multivariate data analysis (6th ed.). Upper Saddle River, NJ: Prentice Hall.

Hair, J. F., Ringle, C., \& Sarstedt, M. (2011). PLS-SEM: Indeed a silver bullet. Journal of Marketing Theory and Practice, 19(2), 139-51.

Hammitt, W. E., Backlund, E. A., \& Bixler, R. D. (2006). Place bonding for recreation places: Conceptual and empirical development. Leisure Studies, 25, 17-41.

Hammitt, W. E., Kyle, G. T., \& Oh, C-O. (2009). Comparison of place bonding models in recreation resource management. Journal of Leisure Research, 41(1), 57-72.

Hidalgo, M. C., \& Hernandez, B. (2001). Place attachment: Conceptual and empirical questions. Journal of Environmental Psychology, 21, 273-281.

Hightower Jr., R., Brady, M. K., \& Baker, T. L. (2002). Investigating the role of the physical environment in hedonic service consumption: an exploratory study of sporting events. Journal of Business Research, 55(9), 697-707.

Hill, B., \& Green, C. (2000). Repeat attendance as a function of involvement, loyalty, and the sportscape across three football contexts. Sport Management Review, 3(2), 145-162.

Hulland, J. (1999). Use of partial least squares (PLS) in strategic management research: A review of four recent studies. Strategic Management Journal, 20, 195-204.

International Olympic Commitee. (2015). Olympic agenda 2020: 20+20 recommendations. Lausanne, Switzerland: Author.

Jorgensen, B. S., \& Stedman, R. (2006). A comparative analysis of predictors of sense of place dimensions: Attachment to, dependence on, and identification with lakeshore properties. Journal of Environmental Management, 79, 316-327.

Kaplanidou, K. (2006). Affective event and destination image: Their influence on Olympic travelers' behavioral intentions. Event Management, 10(2-3), 159-173.

Kaplanidou, K., \& Vogt, C. (2007). The interrelationship between sport event and destination image and sport tourists' behaviours. Journal of Sport \& Tourism, 12(3-4), 183-206.

Korpela, K. M., Hartig, T., Kaiser, F. G., \& Fuhrer, U. (2001). Restorative experience and self-regulation in favourite places. Environment and Behavior, 33, 572-589.

Kyle, G. T., Graefe, A., Manning, R., \& Bacon, J. (2003). An examination of the relationship between leisure activity involvement and place attachment among hikers along the Appalachian Trail. Journal of Leisure Research, 35, 249-273.
Kyle, G., Mowen, A., \& Tarrant, M. (2004). Linking place preferences with place meaning: An examination of the relationship between place motivation and place attachment. Journal of Environmental Psychology, 24, 439-454.

Lalli, M. (1992). Urban-related identity: Theory, measurement and empirical findings. Journal of Environmental Psychology, 12, 285-303.

Lee, J., Kyle, G., \& Scott, D. (2012). The mediating effect of place attachment on the relationship between festival satisfaction and loyalty to the festival hosting destination. Journal of Travel Research, 51(6), 754-767.

Lewicka, M. (2011). Place attachment: How far have we come in the last 40 years? Journal of Environmental Psychology, 31, 207-230.

London 2012. (2004). Candidate file. Part 1: Olympic Games concept and legacy. Retrieved from http://webar chive.nationalarchives.gov.uk/20070305103412/http:// www.london2012.com/documents/candidate-files/the me-1-olympic-games-concept-and-legacy.pdf

Long, K. (2012, July 26). The Aquatics Centre: At the heart of the Stingray. London Evening Standard.

Low, S. M. (1992). Symbolic ties that bind. In I. Altman \& S. M. Low (Eds.), Place attachment (pp. 165-185). New York: Plenum Press.

Low, S. M., \& Altman, I. (1992) Place attachment: A conceptual enquiry. In I. Altman \& S. M. Low (Eds.), Place attachment (pp. 1-12). New York: Plenum Press.

McAndrew, F. T. (1998). The measurement of "rootedness" and the prediction of attachment to home-towns in college students. Journal of Environmental Psychology, 18, 409-417.

McCabe, S., \& Stokoe, E. H. (2004). Place and identity in tourists' accounts. Annals of Tourism Research, 31(3), 601-622.

McClinchey, K., \& Carmichael, B. (2010). The role and meaning of place in cultural festival experiences. In M. Morgan, P. Lugosi, \& J. R. B. Ritchie (Eds.), The tourism and leisure experience (pp. 59-77). Bristol, UK: Channel View.

Moore, R. L., \& Graefe, A. R. (1994). Attachments to recreation settings. Leisure Sciences, 16, 17-31.

Nunnally, J. C., \& Bernstein, I. H. (1994). Psychometric theory. New York: McGraw-Hill.

Oliver, R. (1997). Satisfaction: A behavioral perspective on the consumer. New York: McGraw-Hill.

Penny, S., \& Redhead, S. (2009). We're not really here: Manchester City, mobility and placelessness. Sport in Society, 12(6), 755-764.

Prayag, G., \& Ryan, C. (2012). Antecedents of tourists' loyalty to Mauritius: The role and influence of destination image, place attachment, personal involvement and satisfaction. Journal of Travel Research, 51(3), 342-356.

Proshansky, H. M. (1978). The city and self-identity. Environment and Behavior, 10, 147-169.

Proshansky, H. M., Fabian, A. K., \& Kaminoff, R. (1983). Place identity: The physical world and socialization of the self. Journal of Environmental Psychology, 3, 57-83. 
Ramkissoon, H., Smith, L. D. G., \& Weiler, B. (2013). Testing the dimensionality of place attachment and its relationships with place satisfaction and pro-environmental behaviours: A structural equation modelling approach. Tourism Management, 36, 552-566.

Relph, E. (1976). Place and placelessness. London: Pion.

Ren, X. (2008). Architecture and nation building in the age of globalization: Construction of the National Stadium of Beijing for the 2008 Olympics. Journal of Urban Affairs, 30(2), 175-190.

Ringel, N., \& Finkelstein, J. (1991). Differentiating neighbourhood satisfaction and neighbourhood attachment among urban residents. Basic and Applied Social Psychology, 12(2), 177-193.

Rosen, D. E., \& Surprenant, C. (1998). Evaluating relationships: Are satisfaction and quality enough? International Journal of Service Industry Management, 9(2), 103-125.

Sato, M., Jordan, J. S., \& Funk, D. C. (2014). The role of physically active leisure for enhancing quality of life. Leisure Sciences, 36(3), 293-313.

Shipway, R., \& Kirkup, N. (2011). Understanding sport tourism experiences: Exploring the participant-spectator nexus. In R. Sharpley \& P. Stone (Eds.), Tourist experiences: Contemporary perspectives (pp. 127-139). Abingdon, UK: Routledge.

Smith, A. (2005a). Reimaging the city: The value of sport initiatives. Annals of Tourism Research, 32(1), 217-236.

Smith, A. (2005b). Conceptualizing city image change: The "re-imaging" of Barcelona. Tourism Geographies, 7(4), 398-423.

Stedman, R. C. (2003). Is it really just a social construction: The contribution of the physical environment to sense of place. Society and Natural Resources, 16, 671-685.

Theodorakis, N. D., Koustelios, A., Robinson, L., \& Barlas, A. (2009). Moderating role of team identification on the relationship between service quality and repurchase intentions among spectators of professional sports. Managing Service Quality, 19(4), 456-473.

Tuan, Y-F. (1974). Space and place: humanistic perspective. Progress in Geography, 6, 233-246.

Twigger-Ross, C. L., \& Uzzell, D. L. (1996). Place and identity processes. Journal of Environmental Psychology, 16(3), 205-220.

Uhrich, S. A., \& Benkenstein, M. (2010). Sport stadium atmosphere: Formative and reflective indicators for operationalizing the construct. Journal of Sport Management, 24, 211-237.

Van Aalst, I., \& Van Melik, R. (2012). City festivals and urban development: Does place matter? European Urban and Regional Studies, 19(2), 195-206.

Vertinsky, P., \& Bale, J. (Eds.). (2004). Sites of sport: Space, place, experience. London: Routledge.

Vinzi, V. E., \& Russolillo, G. (2010). Partial least squares path modeling and regression. In Y. S. E. Wegman \& D. Scott (Eds.), Wiley interdisciplinary reviews: Computational statistics. New York: Wiley.

Wetzels, M., Odekerken-Schroder, G., \& Van Oppen, C. (2009). Using PLS path modeling for assessing hierarchical construct models: Guidelines and empirical illustration. MIS Quarterly, 33(1), 177-195.

Wochnowski, H. (1996). Event marketing-foundations and design recommendations for the marketing of events. Frankfurt, Germany: Peter Lang.

Yoshida, M., \& James, J. D. (2010). Customer satisfaction with game and service experiences: Antecedents and consequences. Journal of Sport Management, 24, 338-361.

Yuksel, A., Yuksel, F., \& Bilim, Y. (2010). Destination attachment: Effects on customer satisfaction and cognitive, affective and conative loyalty. Tourism Management, 31, 274-284.

Zeithaml, V. A., \& Bitner, M. J. (2003). Services marketing: Integrating customer focus across the firm. New York: McGraw-Hill. 